\title{
How Heavy Metal contamination is contributing pollution in Delhi
}

\author{
Shalini Arora ${ }^{1}$, Dr. Rama Lokhande ${ }^{2}$ \\ ${ }^{1}$ Department of Basic Science, Jaipur National University, Jaipur, Rajasthan, India \\ Email: shaliniarora30@gmail.com \\ ${ }^{2}$ Department of Basic Science, Jaipur National University, Jaipur, Rajasthan, India
}

\begin{abstract}
Inexpensive and environmentally supportable corrective choices are compulsory to reinstate polluted lands so as to decrease the connected risks, make the land resource available for agricultural production, enhance food security, and scale down land tenure problems. In evolving countries with great population density and scarce funds available for environmental restoration.

Comparative study of all the important metals according to Region, Population, Public places in Delhi's Soil.
\end{abstract}

Keywords-Heavy Metal, Contamination, Delhi's Soil, Polluted site, NCR zone.

\section{INTRODUCTION}

The acquisitive use of biosolids for polluting soils with heavy metals has caused great concern about their uses in cultivation ${ }^{1}$. Heavy metals most usually found in biosolids are $\mathrm{Pb}, \mathrm{As}, \mathrm{Zn}, \mathrm{Cd}, \mathrm{Fe}$ and $\mathrm{Ni}$, and the metal mass percentage in soil ratio are responsible for its cultivation the mass ration changes by the countryside and the intensity of the industrial commotion, as well as the type of procedure employed during the biosolids handling ${ }^{2}$. Under different circumstances, metals added to soils in applications of biosolids can be percolated downwards through the soil profile and can have the probable to contaminate groundwater ${ }^{3}$. Recent studies on some New Zealand soils treated with biosolids have shown increased concentrations of $\mathrm{Cd}, \mathrm{Ni}$, and $\mathrm{Zn}$ in drainage leachates which is also in sighted in the present research in Delhi's soil $^{4,5}$.

\section{MATERIAL \& METHOD}

When plasma energy is given to an analysis sample from outside, the component elements (atoms) are excited. When the excited atoms return to low energy position, emission rays (spectrum rays) are released and the emission rays that correspond to the photon wavelength are measured. The element type is determined based on the position of the photon rays, and the content of each element is determined based on the rays' intensity. Plasma is the forth state of matter, next to the solid, liquid and gaseous state. In the ICP-OES the plasma is generated at the end of a quarts torch by a cooled induction coil through which a high frequency alternate current flows. As a consequence, an alternate magnetic field is induced which accelerated electrons into a circular trajectory. Due to collision between the argon atom and the electrons ionization occurs, giving rise to a stable plasma. The plasma is extremely hot, 6000-7000 K. In the induction zone it can even reach $10000 \mathrm{~K}$.

$\begin{aligned} & \text { \% Relative Standard } \\ & \text { Deviation }(\% \text { RSD })=\end{aligned} \frac{\text { Standard Deviation }}{\text { Mean Value }} \times 100$

III. INTENSITY OF SPECIFIC METAL IN SOIL OF PUBLIC TRANSPORTATION Table.6.4: Public Transportation

\begin{tabular}{|l|r|r|r|r|r|r|r|r|r|r|}
\hline & D99 & D101 & D72 & D45 & D29 & D31 & D35 & D36 & D37 \\
\hline As 188.979 & -2.9 & -3.5 & -3.9 & -6.5 & -0.2 & 4.3 & 2.1 & -4 & -4.8 \\
\hline Cd 228.802 & 14 & -5.4 & 16 & -1.1 & 13 & 11.7 & 6.2 & 14.1 & 8.3 \\
\hline Fe 238.204 & 1068870.4 & 973691.3 & 1134006.1 & 1350420.1 & 1138255.6 & 1023822.2 & 1127767.4 & 988009 & 1417410.1 \\
\hline Ni 231.604 & 580.9 & 665.5 & 601.2 & 635.7 & 576.7 & 517.1 & 503.6 & 473.8 & 489.4 \\
\hline Pb 220.353 & 108.7 & 119.5 & 103.7 & 66.1 & 81 & 96 & 50.7 & 72.9 & 71.7 \\
\hline Zn 206.200 & 4484.8 & 2595.4 & 24859.6 & 1947.4 & 3087.9 & 4400.4 & 1271.6 & 1695.7 & 3174.3 \\
\hline
\end{tabular}

1-Public Transportation -Some Specific Metals 

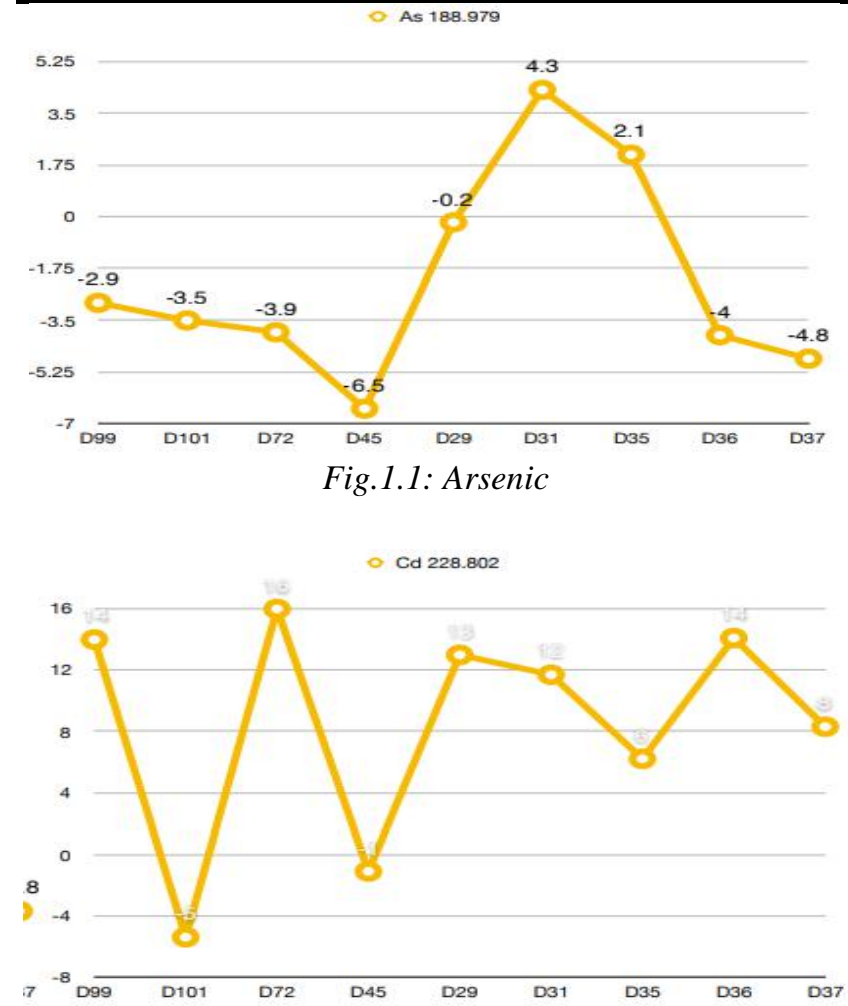

Fig.1.2: Cadmium

\section{Fe 238.204}

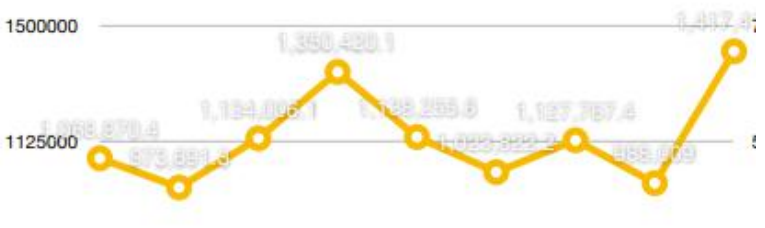

750000

375000

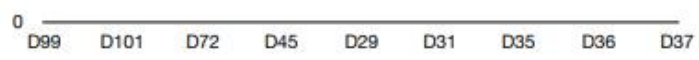

Fig.1.3: Iron

$\circ$ Ni 231.604

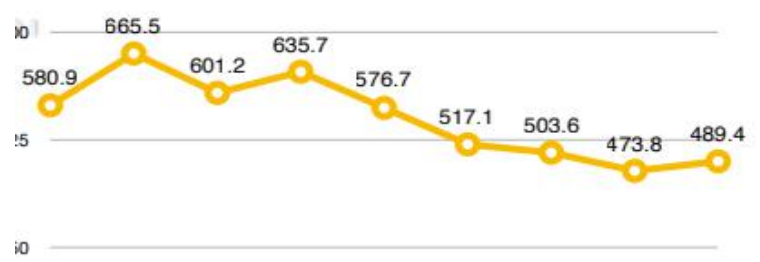

5

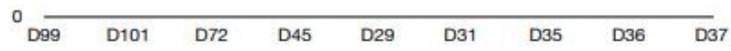

Fig. 1.4: Nickel

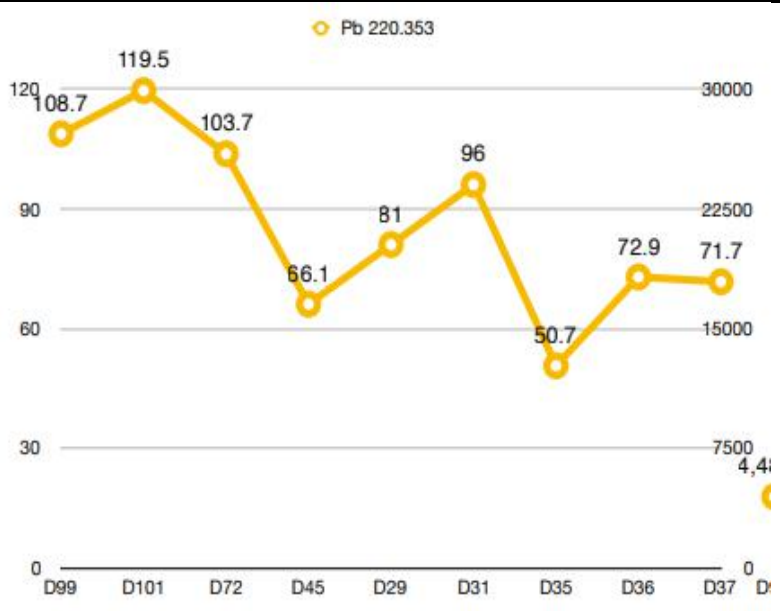

Fig. 1.5: Lead

On 206.200

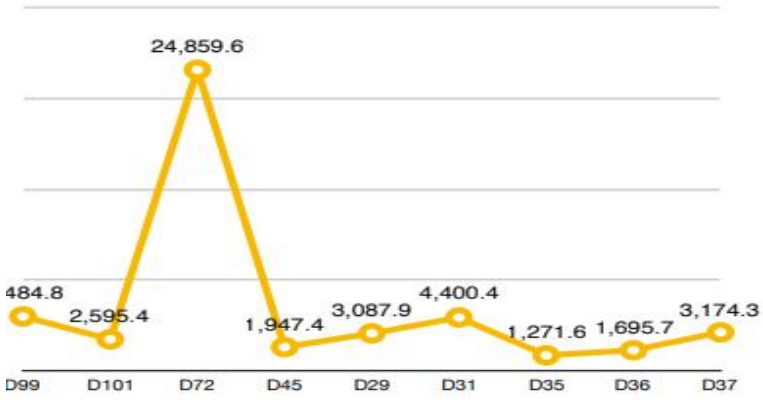

Fig.1.6: Zinc

\section{DISUSSION}

1. Arsenic (Fig.1.1)-The magnitude of as was found maximum in (D31) \& least in (D45), it suggest most anthropogenic in these areas.

2. Cadmium (Fig.1.2)- Similar trend was observed in Cd concentration was least in (D101) \& most in (D72), in rest of the places reported the same in rest of the areas.

3. Iron (Fig.1.3)-Iron being vital metal for the soil, abundantly present in soil, was found most Fe rich area for soil.

4. Nickel (Fig.1.4)-Maximum intensity of $\mathrm{Ni}$ was observed in all the areas of public transport which is evident for mechanical or automotive activities.

5. Lead (Fig.1.5)- The presence of Lead $(\mathrm{Pb})$ was almost equally and abundantly reported in all the soil samples, Maximum intensity of $\mathrm{Pb}$ was observed in all the areas of commuting, it tells the use of Automobiles \& fuels is almost equal in all the places.

6. Zinc (Fig.1.6)-Zinc should be more likely present in the soil, for the nutrient value of soil , $\mathrm{Zn}$ was least reported in all the places except (D72) having exceptionally high concentration in soil. 


\section{CONCLUSION}

Table.5.1: Public Transportation

\begin{tabular}{|c|c|c|}
\hline S.No. & Metal & Public Transportation \\
\hline 1 & $\begin{array}{c}\text { As } \\
188.979\end{array}$ & $\begin{array}{l}\text { The magnitude of As was found } \\
\text { most near AIIMS Hospital \& least } \\
\text { Delhi's International Airport. }\end{array}$ \\
\hline 2 & $\begin{array}{c}\text { Cd } \\
228.802\end{array}$ & $\begin{array}{l}\text { Similar trend was observed in Cd } \\
\text { concentration was least on } \\
\text { Kashmiri gate ISBT. \& most in } \\
\text { Anand Vihar Metro. }\end{array}$ \\
\hline 3 & $\begin{array}{c}\text { Fe } \\
238.204\end{array}$ & $\begin{array}{l}\text { Iron being vital metal for the soil, } \\
\text { abundantly present in soil, was } \\
\text { found most Fe rich area for soil. }\end{array}$ \\
\hline 4 & $\begin{array}{c}\mathrm{Ni} \\
231.604\end{array}$ & $\begin{array}{l}\text { Maximum intensity of } \mathrm{Ni} \text { was } \\
\text { observed in all the areas of public } \\
\text { transport which is evident for } \\
\text { mechanical or automotive } \\
\text { activities. }\end{array}$ \\
\hline 5 & $\begin{array}{c}\mathrm{Pb} \\
\mathbf{2 2 0 . 3 5 3}\end{array}$ & $\begin{array}{l}\text { Maximum intensity of } \mathrm{Pb} \text { was } \\
\text { observed in all the areas of } \\
\text { commuting }\end{array}$ \\
\hline 6 & $\begin{array}{c}\mathrm{Zn} \\
206.200\end{array}$ & $\begin{array}{l}\text { Anand Vihar being on outskirts of } \\
\text { Delhi, having exceptionally high } \\
\text { concentration in soil. }\end{array}$ \\
\hline
\end{tabular}

Heavy metal contamination of soil is carriage of dangers and hazards to human beings and the biological network through: straight incorporation or contact with contaminated soil, the food chain (soil-plant-human or soil-plant-animal human), drinking of contaminated ground water, decrease in food quality (safety and marketability) via phytotoxicity, lessening in land usability for agricultural production causing food insecurity, and land occupancy difficulties ${ }^{5.6,7}$.

\section{REFERENCES}

[1] R. Canet, F. Pomares, F. Tarazona, and M. Estela, "Sequential fractionation and plant availability of heavy metals as affected by sewage sludge applications to soil," Communications in Soil Science and Plant Analysis, 1998,29,(5-6),697-716.

[2] S.V. Mattigod and A. L. Page, "Assessment of metal pollution in soil," in Applied Environmental Geochemistry Academic Press, London, UK, 1983. 355-394.

[3] R. G. McLaren, L. M. Clucas, and M. D. Taylor, "Leaching of macronutrients and metals from undisturbed soils treated with metal-spiked sewage sludge.3. Distribution of residual metals," Australian Journal of Soil Research, 2005,43, (2) 159-170.

[4] D. R. Baldwin and W. J. Marshall, "Heavy metal poisoning and its laboratory investigation," Annals of Clinical Biochemistry, 1999,36, (3),267-300.
[5] M. J. McLaughlin, B. A. Zarcinas, D. P. Stevens, and N. Cook, "Soil testing for heavy metals," Communications in Soil Science and Plant Analysis,2000,31(11-14), 1661-1700.

[6] M. J. McLaughlin, R. E. Hamon, R. G. McLaren, T. W. Speir, and S. L. Rogers, "Review: a bioavailability-based rationale for controlling metal and metalloid contamination of agricultural land in Australia and New Zealand," Australian Journal of Soil Research, 2000, 38(6),1037-1086.

[7] W. Ling, Q. Shen, Y. Gao, X. Gu, and Z. Yang, "Use of bentonite to control the release of copper from contaminated soils," Australian Journal of Soil Research,45(8), 618-623, 2007. 